\title{
Ruské dějiny charvátské literatury
}

\author{
Ivan Dorovský (Brno)
}

Galina Jakovlevna Iljina: Chorvatskaja literatura XX veka. Moskva: Indrik, 2015. 437 s. ISBN 978-5-91674359-3.

Akademická a vysokoškolská pracoviště u nás v minulosti oznamovala, že mají ve svých odborných plánech zpracování a vydání dějin jednotlivých slovanských národních literatur. Ovšem nikdy nebyly u nás kompletně a samostatně vydány dějiny polské, bulharské, srbské, charvátské či makedonské literatury. Máme u nás díky jugoslavistovi Viktoru Kudělkovi pouze první samostatně napsané dějiny slovinské literatury doprovázené literárním lexikonem.

V Rusku vyšly zatím ve třech svazcích souborně dějiny literatur západních a jižních Slovanů (Istorija literatur zapadnych $i$ južnych slavjan. V 3 tomach, 1997-2001) a slovník literatur jižních Slovanů (Leksikon južnoslavjanskich literatur, 2012).

Chorvatskaja literatura XX veka autorky Galiny Jakovlevny Iljinové poprvé v Rusku vědecky zpracovává dějiny charvátské literatury 20. století. Seznamuje nás se zvláštnostmi jejího vývoje v uplynulém století a pomáhá pochopit tvưrčí i společenské procesy, které probíhaly od roku 1900, kdy se formoval žánrově stylový systém a završily se pozitivní kontakty především s italskou, německy psanou rakouskou, mad'arskou a ruskou literaturou, až do vytvoření samostatné republiky v roce 1990 .

Všechny procesy hledání nových estetických směrů, které v Charvátsku probíhaly druhé polovině 20. století, včetně obhajoby národního vědomí, našly svou důslednou realizaci na pomezí 19. a 20. století v charvátské moderně. Realistická literatura, do níž pronikaly socialistické myšlenky, prohloubila svou sociální analýzu, rozšírila politickou a společenskou problematiku. Spolupůsobila s modernistickými proudy, které pomáhaly zesílit subjektivně lyrický princip. Působila na vytvoření modernismu v charvátské literatuře tím, že její představitelé totálně odmí- tali společenskou problematiku a soustřed’ovali se na vnitřní svět každého individua. Obdobím moderny fakticky začínají dějiny charvátské literatury 20. století.

V průběhu historického vývoje byli Charváti téměř tisíc let v cizím područí. Ve 20. století pak žili ve čtyřech státních útvarech: Do roku 1918 patřili k Rakousko-Uhersku, mezi dvěma světovými válkami (1918-1941) žili v Království Jugoslávie, poté v Nezávislém charvátském státě (1941-1945) a nejdéle pak byli v letech 19451990 součástí jugoslávské socialistické federace. Suverénní Charvátsko vyhlásilo nezávislost v roce 1991.

Autorka přijala Ďurišinovu a Dorovského teorii o dvojdomosti a biliterárnosti a uznává, že úzké styky s kulturou v různém sociokulturním prostředí vedly $\mathrm{k}$ tomu, že dílo mnoha literárních a kulturních tvůrců patří ke dvěma literaturám a kulturám. Vývoj jednotlivých literárních období, která se téměř shodují s historickým vývojem, sleduje podle zvoleného schématu: próza, poezie, drama. Pouze nejdelší literární vývoj období socialismu dělí dále na menší celky.

Jak rozsahem, tak také př́ínosem tvoří jádro práce autorčin výklad o desetiletích od osvobození po šedesátá léta (1945-1960). Píše o zvláštnostech federace, v níž fungoval centralizovaný hospodářský, politický a ideologický organismus. Ukazuje, že ve skutečnosti byla federace autoritativní stát, vedený komunistickou ideologií. Činnost jakékoliv opozice byla na čtyřicet let potlačena. Novou ideologii prosazoval do života tzv. agitprop, tj. oddělení agitace a propagandy při ÚV strany. V letech 1945-1952 byl v jeho čele Milovan Đilas (1911-1995). Hlavní oporou agitpropu byli literární tvůrci, kteří se aktivně zúčastnili národně osvobozeneckého boje. Faktorem nestability jugoslávské společnosti byly 
různě se prolínající odstředivé a dostředivé tendence. Z kolaborace byli obviněni nejen ustašovci, nýbrž také značná část inteligence. Byli mezi nimi rovněž významní literární tvưrci (T. Ujević, D. Tadijanović, J. Benešić aj.). Určitou dobu nesměl publikovat dokonce ani M. Krleža. Mnozí literáti byli nuceni odejít do zahraničí.

G. J. Iljinová uvádí, že v prvních letech po osvobození se veškerá kulturně osvětová činnost realizovala rovněž prostřednictvím všech forem umělecké tvorby. Probíhala usilovná práce při šíření kultury: byla zakládána kulturní střediska, knihovny, divadla, kluby, státní nakladatelství a tiskárny, literární časopisy a denní listy, v nichž vznikly pravidelné kulturní rubriky. Svaz charvatských spisovatelů začal vydávat časopis Republika. V Jugoslávii se vydávala ve vysokých nákladech díla současných jugoslávských tvůrců i zahraničních klasiků. Podle Iljinové bylo to zároveň období aktivní politizace společnosti a její kultury, absolutizace revolučního systému hodnot. Z národních tradic se dávala přednost revoluční tvorbě meziválečného a válečného období, tj. sociální literatuře a sociálnímu realismu. Všechny knihy, původní i přeložené, byly dostupné na celém území jugoslávské federace.

Autorka stručně, ale přehledně uvádí, co se v uvedeném období překládalo a vydávalo z tehdejší sovětské kritiky a literárních dějin, která díla ruských klasiků i současných sovětských autorů byla překládána a masově vydávána. Zjištujeme, že tatáž odborná a literární díla se překládala také u nás, To všechno v prvních letech do vzniku konfliktu mezi Jugoslávií a Sovětským svazem (červen 1948, listopad 1949). Po něm se do popředí dostal kult osobnosti Josipa Broze Tita, který vytyčil jugoslávský model socialismu v podobě samosprávy. Titoismus, o němž se u nás vůbec nemluvilo, se upevňoval pomocí masových represí, koncentračními tábory, vyloučením ze společenského života všech, kteří smýšleli jinak. O tom všem se až do roku 1970 ani v tisku, ani v umělecké tvorbě nesmělo psát.

Ovšem už koncem roku 1949 na 2. sjezdu spisovatelů Jugoslávie zaznělo také něco nového. Ozvaly se některé hlasy, které prosazovaly estetický pluralismus. Pro kulturní život země měl dalekosáhlý význam referát M. Krleži $O$ svobodě kultury, který přednesl na 3. sjezdu jugoslávských spisovatelů v Lublani v roce 1952. Kritizoval v něm mj. sovětský model umění, aniž se ovšem dotkl domácí praxe. Krležovo vystoupení bylo přijato jako oficiální rozchod se socialistickým realismem. Vneslo nový duch, který umožnil návrat do literatury těch tvưrců, jež byli vyloučeni. Byla založena nová periodika. Největší úlohu sehrál časopis Krugovi (1952-1958), který se podle kritiky stal estetickou a etickou školou, v níž se formovaly literární osobnosti a směry činnosti poválečné generace. Kolem časopisu se shromáždila skupina převážně třicátníků, kteří se přirozeně nemohli účastnit národně osvobozeneckého boje. Jejich zásadou se stalo heslo $A t^{\prime} j e$ živo, s kterým vystoupil Vlatko Pavletić. Na stránkách Kruhů se objevovaly texty proti dogmatismu a překrucování tradic. Stále častěji do něho psali autoři srbské, charvátské i slovinské moderny z pomezí století i meziválečné avantgardy, tiskly se překlady děl G. Apollinaira, F. Kafky, E. Hemingwaye, A. Camuse, J. P. Sartra. Projevil se výrazný zájem o A. Bělého, I. Babela, B Pilnjaka, B. Pasternaka.

Všechny pokusy mladých prosadit svobodu volby témat a výrazových prostředků i právo na experiment byly označeny jako jalový formalismus a oživení surrealismu a považovaly se pro socialistickou společnost za nepřijatelné. Stranické vedení proto prrijalo četná represivní opatření, o nichž se např. u nás nevědělo: docházelo k zákazu časopisů, divadelních inscenací a filmů.

Reakce literární a kulturní fronty vyústila v novém sepětí pod názvem socialistický estetismus. Termín sjednocoval značně široký okruh jevů, cílem tvůrců bylo zbavit se ideologického tlaku, rozbít mýtus o ideologické a estetické jednotě umění v socialistické Jugoslávii.

Autorka správně poukazuje na úlohu, kterou sehrála skupina charvátských vědců vysokých škol, jejíž jádro tvořili germanisté Zd. Škreb a V. Žmegač, romanista I. Frangeš a rusista A. Flaker, kteří vypracovali vědecké postupy hodnocení uměleckého díla, historických procesů a současného stavu literatury. Založili tak 
tzv. záhřebskou stylistickou školu a sjednotili kolem časopisu Umjetnost riječi, který vydávali, mnoho domácích a zahraničních odborníků. $\mathrm{V}$ průběhu let seznámili čtenáře s pracemi napřr. L. Spitzera, E. Staigera, ruských formalistů aj.

Počátkem šedesátých let (po přijetí nové ústavy) se začaly projevovat mnohé dezintegrační tendence, mj. se projevovaly požadavky větší samostatnosti republik, včetně oblasti kultury. Rozpadl se jugoslávský svaz spisovatelů. Nastoupila nová generace, která založila svůj orgán Razlog (1961-1968). Tzv. obraznou poezii vystřídala tvorbou racionální mluvy a metajazykovou a konceptuální poezií.

V druhé polovině šedesátých let vystoupily na povrch četné politické, sociální, ideologické a národnostní protiklady. V roce 1968 se v Jugoslávii, stejně jako v mnoha dalších evropských zemích, šírily studentské demonstrace. Znamenaly jasnou krizi socialistické společnosti, v Charvátsku spolu s požadavky hospodářské a politické samostatnosti vystoupily ostře do popředí národnostní a jazykové otázky. S podporou republikových stranických orgánů i širokých kruhů inteligence podepsaly vědecké instituce, především Matice charvátská, Deklaraci o postaveni a názvu charvátského spisovného jazyka. Tak dostaly otázky jazyka a dějin charvátské státnosti politickou povahu. Nejvyšší jugoslávské vedení proto přistoupilo $\mathrm{k}$ tvrdým represivním opatřením: zakázalo Matici charvátskou a několik literárních časopisů, vylučovalo ze strany, zatýkalo studentské vůdce a mnoha kulturním činitelům byla zakázána veřejná a publikační činnost. Pro charvátskou společnost a její literaturu to znamenalo nové období vývoje.

Vývoj charvátské poválečné prózy v prvních letech po osvobození probíhal obdobně, jako u ostatních jugoslávských a evropských národních literaturách. Miroslav Krleža měl v poválečném období zvláštní postavení. Zachovával se k němu opatrnický vztah kvůli jeho neúčasti v národně osvobozenecké válce i kvůli názorům na svobodu tvorby, které zastával mezi válkami. Počátkem padesátých let však vedení využilo Krležovy autority $\mathrm{k}$ upevnění jugoslávské varianty socialismu. Přispěl k tomu ostatně sám Krleža, který na 3. spisovatelském sjezdu ostře kritizoval sovětský socialistický realismus, ale ani slovem se nezmínil o situaci v Jugoslávii. Po celý život prosazoval princip, že tvưrce by měl mít talent, znalosti, mistrovství a vkus. Jeho autorita se upevňovala, vycházely jeho sebrané spisy, oslavovala se jubilea, v divadlech po celé Jugoslávii se uváděly jeho divadelní hry, upoutal pozornost J. B. Tita. To vše vytvářelo kolem Krleži atmosféru kultu.

Autorka věnuje Krležovu rozsáhlému prozaickému a dramatickému dílu patřičnou pozornost. Charakterizuje monumentální pětisvazkové plátno Prapory a poznamenává, že podobný typ románu se objevil také v jiných evropských literaturách (T. Mann, J. Iwaszkiewicz, E. Stanev). Sovětská kritika jej nazvala subjektivní epopejí.

$\mathrm{V}$ druhé polovině padesátých let nastoupila nová generace. Vnesla do literatury současnou tematiku, která obsahovala svo̊j systém hodnot, poněkud odlišný od socialistického systému. Podobný proces se ovšem prosadil ve všech jugoslávských národních literaturách. Do popředí se dostávaly otázky odcizení a lhostejnosti. V literárních dílech se odhaloval typ banálního, smutného, šedého, lhostejného člověka. Autoři nejčastěji hledali východisko v metafyzických otázkách. To je však vedlo $\mathrm{k}$ existencialismu. V charvátské literatuře prakticky kromě expresionismu nebyly žádné tradice avantgardy. Proto nastal jakýsi návrat k tradicím domácí moderny a meziválečného modernismu, který literární historie nazvala modernismus 2.

Po charakteristice hlavních děl žijícího klasika Antuna Šoljana (1932-1993), který se projevil nejen jako prozaik, nýbrž také jako básník, dramatik, literární kritik a překladatel a sestavil na tu dobu významné antologie západoevropských, americké a ruské literatury, autorka podala přehled vývoje poválečné básnické a dramatické tvorby. Je chvályhodné, že Iljinová uvedla básníka Maka Dizdara (1917-1971) jako dvojdomého. Sám autor se totiž považoval za bosenskohercegovského a charvátského tvưrce, který přispěl k rozvoji obou národních literatur.

Z dramatiků uvádí a charakterizuje vrcholná díla Marjana Matkoviće a zdůrazňuje úlohu, 
kterou v procese estetizace dramatické tvorby sehrála díla dvou autorů - Ranka Marinkoviće a Miroslava Krtleži. Marinkovićovo tragické drama Gloria je první hluboce existenciální, psychologické dílo v charvátské poválečné dramatice. Je stále na repertoáru mnoha divadel bývalé jugoslávské federace.

Krležova poslední divadelní hra Arethaios aneb Legenda o svaté Ancille, rajském ptáku byla sice vydána a uvedena v roce 1959 , začátky jejího vzniku však klade autor do roku 1942. Byla předchůdkyní metaforického dramatického žánru. V šedesátých letech si razí cestu dramata vyjadřující současnou problematiku. Vrátil se k ní Marijan Matković dvěma svými hrami - Jarmark snů a Raněný pták.

Od druhé poloviny šedesátých let se charvátská dramatická tvorba obohacuje různými žánry: stylizací antických námětů, alegorickým zpracováním motivů národních dějin a folkloru i tzv. bytovým a psychologickým dramatem.

Samostatnou pozornost věnuje autorka sedmdesátým a osmdesátým letům, která považuje za významný předěl mezi obdobími v dějinách charvátské literatury. $\mathrm{V}$ těch letech došlo k zákazu nebo výměně redakčních rad několika časopisů, byl ostře kritizován filozofický časopis Praxis (vycházel s přestávkami v letech 1964-1984), v němž byly publikovány texty jak jugoslávských, tak také zahraničních odborníků převážně neomarxistických směrů. Od šedesátých let začaly vycházet vedle děl např. I. Erenburga, bratrů Strugackých, J. Trifonova, B. Pasternaka, A. Achmatovové také práce mladých tvưrců období tzv. tání: J. Jevtušenka, A. Vzonesenského, B. Okudžavy aj., vycházely do té doby zakázané romány $\mathrm{B}$. Pasternaka a A. Solženicyna, čtenáři se seznamovali s díly ve třicátých letech pronásledovaných tvůrců (D. Charms, V. Chlebnikov, Pilnjak, M. Bulgakov aj.). Po Titově smrti (1980) došlo k jistému uvolnění ve společnosti i v kultuře a literatuře.

Další literární a kulturní život sleduje autorka po desetiletích i nadále podle schématu: próza, poezie, drama. V pojednání o sedmdesátých až osmdesátých letech píse o třech aktivních generacích prozaiků: o tvưrcích starší generace (P. Šegedin, R. Marinković, J. Franičević-Pločar aj.). Sem patří také autoři tzv. prózy v džínách. Mirko Sabolović uvedl do poválečné charvátské literatury problematiku současného charvátského venkova, jak to neučinil nikdo před ním. Velmi plodnému prozaiku Ivanu Aralicovi (nar. 1930) získaly jméno a věhlas jeho romány na historické náměty. Jako jednoho z Aralicových učitelů uvádí I. Andriće. K téže generaci jako I. Aralica patří Nedeljko Fabrio (1937), díky němuž se historický román stal převládajícím modelem národní prózy.

Důležitým faktorem formování tvưrčích principů mladých charvátských prozaiků bylo to, že všichni byli absolventy filozofické fakulty. Klíčem k pochopení jejich koncepce je kniha. Nejznámějším tvưrcem této generace je Pavao Pavličić (nar. 1946). Je autorem mnoha detektivních románů, v nichž se žánrově prolínají kriminální a fantastické prvky.

Neméně populární a masově čtené jsou prózy Gorana Tribusona (nar. 1948). Jedno z nejlepších jeho děl je román Slyšiš nás, Frýdo Sternová? Je zpovědí bezejmenného učitele literatury o zamilování několika chlapců do dívky z bohaté židovské rodiny, která se přistěhovala do jejich ulice.

Autokomentář jako rovnoprávná součást literárního textu převládá ve všech prózách také u nás známé autorky Dubravky Ugrešićové (nar. 1949), která svou první sbírku povídek provokativně nazvala Próza o próze. V jedné z nejlepších jejích knih - Prosazování románu-řeky (1988) - se děj odehrává v Záhřebu během několika dnů, kdy probíhají tzv. Záhřebské literární rozhovory. Vrství se v ní jedna kriminální historka za druhou: vražda španělského básníka, Čechovi je ukraden román, který tajně vyvezl ze země, smrt charvátského ministra, vražda člena ruské delegace.

Autorka si nemohla nevšimnout tzv. ženské prózy, o níž se v posledních desetiletích hodně píše i diskutuje nejen v Charvátsku. Kromě již uvedené Ugrešićové uvádí několik dalších autorek (I. Vrkljanová, S. Drakulićová, I. Lukšićová aj.) a zmiňuje se o jejich významnějších prózách. Romány I. Vrkljanové např. znamenají začátek charvátské autobiografické prózy. 
Nastupující básnická generace nijak nemohla zastínit jména D. Tadijanoviće, J. Kaštelana, D. Ivaniševiće, V. Parunové, S. Mihaliće, M. Slavička a některých dalších. Tadijanovićovy volné melodické verše jsou v charvátské literatuře fenoménem. Básník D. Ivanišević spojuje tradiční lyrickou metriku a poetičnost lidového čakavského nářečí se surrealistickými postupy, J. Kaštelan je rytîřem etického poslání krásy a humanismu

Nejvýznamnějšími osobnostmi charvátské poezie v poválečných desetiletích byli Slavko Mihalić a Milivoj Slaviček. Blízkost k filozofii existencialismu způsobilo, že v Mihalićově tvorbě převládají motivy osamění a smutku, zatímco M. Slaviček je básníkem městské každodennosti. Je mu cizí jakákoli abstrakce, patos nebo symbolizace.

Zcela stručně se autorka zmiňuje také o dalších básnických tvưrcích, kteří vstoupili do literatury v posledních dvou třech desetiletích minulého století. Z dramatických autorů Iljinová píše např. o plodných komediografech Fadilu Chadžićovi a M. Matkovićovi. Podle autorky zahájil novou stránku v charvátské a celé jugoslávské dramatické tvorbě nedávno zesnulý Ivo
Brešan, a to uvedením groteskní komedie Představeni Hamleta ve vsi Dolni Mrduša (1971), která se hrála také u nás v Ostravě a v Praze, a četných jeho frašek, tragických frašek a bufonád. Kromě I. Brešana zmiňuje Iljinová Slobodana Šnajdera, jehož dramata vyvolávala protichůdná hodnocení. Dnes se hrají na domácích i zahraničních scénách.

Po velmi stručném výkladu o charvátské literatuře v emigraci autorka správně považovala za užitečné a nezbytné pojednat také o literární tvorbě devadesátých let. A to podobným postupem jako na předcházejících téměř čtyřech stovkách stran. V pětistránkovém závěrečném slovu shrnula autorka svoje výklady a opatřila knihu vybranou bibliografií odborných prací a bibliografií knižních překladů charvátské literatury 20. století do ruštiny. Jmenný rejstřík a jednostránkové anglické resumé publikaci uzavírají.

Monografie G. J. Iljinové o charvátské literatuře je užitečná a potřebná. Poslouží vědeckým pracovníkům, kroatistům a studentům slavistických oborů i čtenářům, kteří se zajímají o literární dějiny slovanských národů.

\section{prof. PhDr. Ivan Dorovský, DrSc.}

Brno, Česká republika

dorovski@volny.cz 